\title{
Prudent Financial Behaviour among Youth: The Role of Financial Attitude
}

\author{
Mohd Zamri Abu Bakar, Saridan Abu Bakar
}

\begin{abstract}
This paper to seek discuss the importance and the role of Financial Attitude (FA) in determine factors to prudent financial behaviour among youth. Arising of financial problems among young age groups in today life has attracted attention of stakeholders in many countries globally because the groups considered as backbone and future country leaders. This paper seeks to discuss the function of FA in ensuring prudent financial decision and improved youth financial behaviour. Further, this paper later expanded from concept and definitions of FA to the effectiveness and the relationship of $F A$ with prudent financial behaviour. Significantly, FA aims at making individuals more financial literate, transform youth to change for prudent financial decisions and provide them with the skills and competencies to take more responsibilities in their personal financial management.
\end{abstract}

Keywords: attitude, behavior, youth, financial, prudent

\section{INTRODUCTION}

The rising number of various forms of debts and financial problems involving the younger generation who have been declared bankrupt is significant proof that the current young generation having difficulties in managing their personal finance effectively. Emerging of financial market, borderless transaction and global economies slowdown has become great challenges to people around the world irrespective age groups and level of incomes (Klapper, Lusardi \& Van Oudheusden, 2015). Poor financial attitude (FA) and lack of financial knowledge are among the factors identified that trapped many of the younger generation to spend impulsively, living beyond their means and caused them to be trapped in heavy debts and ending in various financial problems. As an amicable solution, various strategies and financial education initiatives has been introduced by respective countries either from governments or private sectors as a platform for the young generation to equip themselves with financial information's to enable them to make informed decisions, become competent financial manager and to be financial literate citizens.

The increasing importance of possessing prudent financial behaviour and good financial practices in today's life has attracted the attention of stakeholders in many countries in the world, irrespective of their political affiliations, economic status and country prosperities in development (Mason \&

Revised Manuscript Received on April 15, 2020.

* Correspondence Author

Mohd Zamri Abu Bakar*, Faculty of Business Management, University Technology MARA, Shah Alam, Malaysia.

Saridan Abu Bakar, Arshad Ayub Graduate Business, University Technology MARA, Shah Alam, Malaysia

(c) The Authors. Published by Blue Eyes Intelligence Engineering and Sciences Publication (BEIESP). This is an open access article under the CC BY-NC-ND license (http://creativecommons.org/licenses/by-nc-nd/4.0/)
Madden, 2017). Today's financial environment scenarios are getting more robust with various offers of financial services and products available in the market to tailor consumer demands and trends (Smith, Synowka \& Smith, 2014; Zhao, Deng \& Zhou, 2017). It has become a great challenge for an individual, irrespective of age groups, households and income groups to manage his or her own financial resources effectively compared with what have been practised and experienced by past generations (Szymborska, 2019). Within the context of consumer markets, business nowadays focus on youth especially college and university students because these groups soon will be graduated, stepping into job market, earning own incomes and managing own financial affairs independently.

Insufficient financial knowledge, poor financial skills, overestimation of financial capability, incompetence in money management coupled with negative financial habits have triggered many youth to be surrounded in serious financial distress due of their inability to make effective money management decisions that highly considered as basic requirements but essential in today's financial life (Rodrigues, Oliveira, Rodrigues \& Costa, 2019). As transactional from youth to young adult, youth in stage learning and experiencing money management independently in day-to-day financial life. Consequently, the situations getting more difficult when they moving out from their parent house, start living on their own and managing financial affairs by experiencing trying and error. The paper aims to discuss the definitions of FA, the important of FA, determinant factors and study the connection between FA and prudent financial behaviour among youth.

\section{LITERATURE REVIEW}

\section{A. FINANCIAL ATTITUDE}

FA refers to disposition towards financial affairs (Ibrahim \& Alqaydi, 2013). Chowa and Despard (2014) defined FA as a individual's state of cognizance, certainty and evaluation related to his/ her own financial matters. It is related to the individual's belief and feeling about money (Falahati \& Paim, 2012). Parotta and Johnson (1998) conceptualised FA as psychological inclination that emerged when a person assessing his/ her financial management practices with some degree of acknowledgement or difference. Paluri and Mehra (2016) in their study conceptualised FA as a personal disposition towards financial affairs. Attitude is defined as a subjective domain and personal attribute (Jain, 2014). Currás-Pérez, Ruiz-Mafé and Sanz-Blas (2013) stated that attitude is a person's predisposition towards a behaviour that emerges from the person's belief on the behaviour. 
In this paper, operationalized definitions of FA refer to disposition of behavioural attitude on financial matters that translates into real action and financial practices.

FA is very important because it influences an individual's behaviour intention in many aspects of financial affairs that include saving, borrowing, risk taking and adverse financial events (Agarwalla, Barua, Jacob \& Varma, 2015; Skagerlund, Lind, Strömbäck, Tinghög \& Västfjälla, 2018). In addition, Shim, Barber, Card, Xiao and Serido (2009) stressed the importance of FA in determining each person financial security in daily active financial life. Falahati and Paim (2012) stated that FA is a strong predictor of financial problems and a preventive measure from being trapped in any financial difficulties. In this sense, understanding the factors that influence how youth manage their expenses in any financial activities remain important because it affect financial decisions and youth money practices or habits of youth. Since youth are in the process of establishing own financial foundation and mostly likely be practising money management through financial experienced, FA can become important predictors in determining youth behaviour intention because the way they think and their perception will affect their present and future financial behaviour.

\section{B. Determinants Of Financial Attitude}

In determining the factors influencing FA, Paluri and Mehra (2016) identified nine variables, namely apprehension, attentiveness in money management affairs, intuitive decisions, precautionary saving, free spending, materialistic and fatalistic attitudes, and the propensity to plan for long- and short-term financial goals. Meanwhile, Fünfgeld and Wang (2009) mentioned that the FA construct consists of anxiety, interest in financial issues, decision styles, need for precautionary saving, and spending tendency. In relation to FA, gender studies have shown that males and females have different levels of FA (Falahati \& Paim, 2012). Nevertheless, women do exhibit a higher score on financial behaviour. Skagerlund et al., (2018) indicated that the central elements of financial savvy could be identified with numeracy and the emotional attitude towards number. Agnew and Harrison (2015) conducted a study on attitude towards debt among English college students and found significant different between female and male in terms of attitude.

Individuals learn and follow attitude and behaviour from their surrounding environment either through modelling, observation, or imitation of people who have contact with them, especially those who are closest them (Bandura, 1986). In terms of development of habits, FA and childhood experiences received during early life will persist and continue into the next stage in life (Duh, 2016). Several studies have indicated that FA is being transmitted mainly from parents (Dohmen, Falk, Huffman, \& Sunde, 2012; Kagotho, Nabunya, Ssewamala, Mwangi, \& Njenga, 2017). However, other socialisation agents such as peers, schools, and media are also important (Fan, \& Chatterjee, 2019). . Norvilitis and Mendes-Da-Silva (2013) showed that parenting plays pivotal roles in shaping students' positive or negative attitude towards money. Irrespective positive or negative FA influence by socialisation agents, it carried significant impact on youth financial management behaviour (Otto \& Webley, 2016). In particular, FA that acquired and developed at early life age, may carry over and become significant predictors of consumption behaviours. In this regards, early life age is considered as a critical stage because it is a foundation for each youth economic security and determinants for FA.

\section{The Relationship With Financial Behaviour}

Numerous studies have documented that FA is a strong predictor influencing intention to successful and is synergistic to behaviour outcomes (Lin, Hsiao \& Yeh, 2017; Massis, 2015; Wang \& Jiang, 2011). FA has been recognised as an important predictor for individuals to manage their personal finance effectively and the key determinant of financial security (Agarwalla et al., 2015; Sohn, Joo, Grable, Lee \& Kim, 2012). Higher level of FA will boost the confidence level of individuals and will further influence them to make right decisions, when they are in the process of evaluating choices or options among available products or services (Mindra \& Moya, 2017). Moreover, FA is widely believed to affect individual financial choice (Agnew \& Harrison, 2015). Due to greater market accessibility and available of product and services, FA has become necessary among youth and carried significant in determining the success of prudent financial practices. Therefore, youth with positive FA are suggested to exhibit effective decision that associated with positive financial behaviour.

Accordingly, FA and behaviour goal within the fields of personal financial contexts, tend to be linked with the individual ability to demonstrate it into real act. Stumm, O'Creevy, \& Furnham (2013) revealed the importance of FA as the target construct in intervention programmes for people who are experiencing adverse financial problems and personal bankruptcy. Joo and Grable (2004) stated that FA and knowledge on financial matters are positively significant to be successful in financial management. Those with sufficient financial knowledge, right financial norms and positive FA in the current market situation are postulated to be able to demonstrate effective financial decisions and achieve better financial well-being. This based on the justification that FA is considered key behaviours instrument will later translated with actual financial decision and further to act accordingly. The impacts of FA on financial behaviour are not limited to money management but in spearhead in any related financial activities that foundation for future economic wellbeing (Saurabh \& Nandan, 2018). Hence, FA can play a strong role as an indicator of financial behaviour.

The association between FA and financial behaviour was supported by research findings from Potrich, Viera, and Mendes-da-Silva (2016). These author found that higher level of money attitude is strongly related with positive financial behaviour, while negative FA is correlated with adverse financial behaviour. However, Paluri and Mehra (2016) pointed out that attitude does not directly influence behaviour. Nevertheless, attitude influences behavioural intentions, which in turn shapes individual real actions. These authors further explained that individuals with higher level of attitude are inclined to behave consistently because knowledge, attitude and behaviour are interrelated. The inclusion of attitude will lead to better outcomes and to make the right financial decisions. In particular, positive FA is correlated with motivation, knowledge application, and learning outcomes (Fong \& Khoo, 2015).

Published By:

Blue Eyes Intelligence Engineering \& Sciences Publication 
Positive FA influences individual judgment to make the best decision on saving, credit, insurance, and remittances (Mindra \& Moya, 2017). Similarly, Lim, Mail, Karim, Ulum, Jaidi and Noordin (2018) stressed on the mediating effects of FA in the association between financial knowledge and behaviour goal to invest. The study found that risk perception and attitude towards individual financial investment are central cognitive elements in the financial behavioural assumption.

Preserving strong FA among young generation is crucial due to the diverse selection of financial products and services. Meanwhile, insufficient financial knowledge has caused negative FA associated with undesirable financial behaviour (Munyoki \& Okech, 2012; Norvilitis \& Mendes-Da-Silva, 2013). Maswati, Abdullah and Wai (2015) stated that knowledge about credit cards, attitude towards utilization of credit cards, and debt management are indicators of credit card practices and financial decisions. Negative attitude towards money and credit cards are correlated with debt behaviour (Ahmed, Ismail, Sadiq, Tabsh \& Alias, 2010). In contrast, positive attitude is correlated with less use of credit card (Ibrahim \& Alqaydi, 2013). Alam, Rahim, Haq, \& Khan, (2014) revealed that positive FA towards credit card has caused deferment in repayment of credit card debts, and is correlated with increase of knowledge in financial management because money has strong roles in terms of emotion and as a commodity in human life (Simkiv, 2013). Consequently, to combat poor usage of credit cards and negative financial behaviour, higher level of FA can become an important attribute and an antidote for any poor financial practices and negative financial behaviour.

Many evidences have shown that FA is strong predictors of savings and determinants of unnecessary spending or abstaining excessive spending (Nyhus \& Webley, 2013; Pham, Yap \& Dowling, 2012). The importance of saving attitude in today's life has been stressed by Ando and Mogliani (1963). The authors said that saving will determine the individual's financial future and they pointed out that the amount of savings must be able to accommodate the respective stages of life. Additionally, empirical evidence suggests that early age is the best time to inculcate positive attitudes towards savings because the process will be carried on and translated into the next stage of life (Gale, Harris \& Levine, 2012). A great concern is that poor saving attitudes at early age may not enable one to sufficiently accumulate funds to cover expenses after retirement, because to save for the future stage in life requires a long process to accumulate funds amid financial uncertainties. Given the diverse of financial challenges, those with right FA able to develop higher propensity to secure financial practices. Thus, it is essential to possess right FA and understand the changes over the time in order to develop positive FA towards prudent financial behaviours.

Higher level of FA may presume practising financial management in investment and risk-avoiding behaviours (Mouna \& Anis, 2017). It is related to a person's ability to discipline himself or herself from unsustainable financial practices (Chong, Francis, Cooper, Abdullah, Hmwee \& Sohod, 2016). This is because individuals are more cautious in the process of making financial decision, to know where to spend their money and to ensure that their money is spent effectively. Individuals with strong FA have a good position accumulated debts. Strong FA towards money can boost

in financial inclusion because of their ability to analyse available financial options on the products or services offered by financial institutions for improving their quality of life (Mindra \& Moya, 2017). For example, Akben-Selcuk (2015) found that students with positive FA tend to pay bills on time, practise budgeting and save their money for future. In their study, Sohn et al., (2012) showed that FA is positive significant with higher level of financial literacy. This results showed that FA is associated with money management effectively, avoidance from any financial risk and predictors to financial decisions.

Empirical evidence has shown that negative FA is a predictor of financial problems among students compared with other variables, regardless of whether they are males or females (Albeerdy \& Gharleghi, 2015; Falahati \& Paim, 2012). Albeerdy and Gharleghi (2015) conducted a study among students at higher learning institution and found that money attitude is positively and significantly associated with students' FL. Academic performance of students with positive FA increases because they do not have to worry about financial matters; and they can concentrate on their studies, and that they are more satisfied with their own financial situation (Archuleta, Dale, \& Spann, 2013). Sohn et al., (2012) investigated adolescents' financial literacy in South Korea and discovered that students possessing higher level of money attitude achieved higher literacy score, while those having negative money attitude scored lower scores in financial literacy. This proved that FA is crucial for youth development and considered as the best platform for making sound financial decisions. FA tend to be positively affected youth financial behaviour and positively influence youth to engage with prudent financial behaviours.

\section{DISCUSSION}

Within the context of money management practices, the behaviour outcome by youth is determined by perceived attitude that youth can control it. In other words, any financial activities of youth are influenced by self-guided own FA and that the higher the degree of FA they have, the strong it is as the predictor for youth to engage in positive financial behaviour. The statement indicated strong evidence that the higher degree of FA could influenced youth to engage in positive financial practices and the stronger is their tendency towards engaging in positive money management practices. This finding is consistent with that of many studies that revealed positive FA could lead to individuals' desirable behavioural intention (Agnew \& Harrison, 2015; Lim et al., 2018).

Individuals' values and perceptions on financial practices, irrespective of positive or negative perceptions, constitute their actual behaviour. Skagerlund et al., (2018) mentioned the important of FA as the determining factor for any individual to become a knowledgeable person because it is associated with the level of financial literacy. The ability for youth to control the state of their own mind is related to the knowledge they possessed and their capability in analysing the consequence of their action. This further influences youth's self-financial judgment and actual financial action.
Blue Eyes Intelligence Engineering \& Sciences Publication (C) Copyright: All rights reserved.

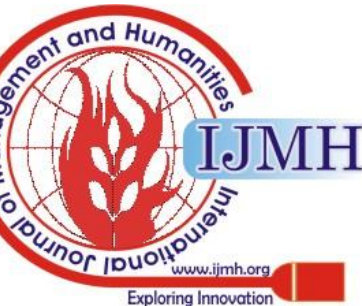


The higher perceived FA influences youth's financial decision, which later will be translated by the individual whether or not to perform the behaviour. Thus, this proved that youth with higher level of positive FA significantly improved their desirable financial behaviour, assisted youth in managing their own financial affairs effectively, secured their own financial well-being, avoided them from any financial vulnerabilities and prevented them from potential bankruptcy at an early life age.

Youth with strong and positive FA are likely to be more able to plan and forecast the consequence of their action, practise saving and avoid themselves from being involved with any excessive buying, compulsive buying or unnecessary spending. Self-guided FA contributes to youth ability to control their spending patterns, analysing financial capability, practise budgeting and efficient financial planning that could help them from deteriorating their own lifestyle. At the same time, perceived higher FA can increase youth motivation to manage financial activities prudently, and are anticipatory factors to keep them from being trapped in compulsive buying, unnecessary spending or various ranges of prospective financial threats.

\section{CONCLUSION}

Prudent financial behaviour is a lifetime objective of everyone and is the foundation for future financial well-being specifically among today youth. The process must begin at an early age of each individual and then further developed, continued and carried over the life course. In present uncertain economic environment with the complex financial environment and the abundance of consumer products and services, the situation requires each persons to acquire and possess sufficient financial skills with strong financial knowledge and sound financial management as tools to manage their own and family financial affairs effectively. This is because the day-to-day financial activities require lots of financial transactions and economic decisions that depend on youth FA, level, skills, financial experience and sufficient degree of financial knowledge. As a result, inculcate positive FA at early life age has been gradually seen as crucial competencies and recognised as the best financial tools that must be acquired by youth as a guide and platform to achieve their financial goals and necessary to achieve present and future financial well-being. Thus, possessing positive FA has been identified as a best to equip youth with sufficient knowledge, information and life skills to assist them to make right financial judgment, to improve their financial behaviour and to be engaged in ideal money management financial practices. The expectation is becoming higher that positive FA will lead youth to become more responsible in money management practices, positive financial behaviour and proficient in managing own financial affairs effectively.

\section{REFERENCES}

1. Alam, S. S., Rahim, R. A., Haq, M. R., \& Khan, M.A.R. (2014). What influence credit card debt in young consumer in Malaysia. Journal of Public Administration, Finance and Law Asian Institute of Finance, 6

2. Ahmed, Z.U., Ismail, I., Sadiq, M. Tabsh, I., \& Alias, H. (2010). Malaysia consumer credit card usage behavior. Asia Pacific Journal or Marketing and Logistic, 22 (4), 528-544.

3. Agarwalla, S. K., Barua, S. K., Jacob, J., \& Varma, J.R. (2015).Financial literacy among working young in urban India. World Development, 67, 101-109.

4. Agnew, S., \& Harrison, N. (2015). Financial literacy and student attitude to debt. A cross national study examining the influence of gender on personal finance concept. Journal of Retailing and Consumer Services, 25, 122-129.

5. Albeerdy, M.I., \& Gharleghi, B. (2015). Determinants of financial literacy among College students in Malaysia. International Journal of Business Administration, 6(3), 15-24.

6. Arceo-Gómez, E. O., \& Villagomez, F. A. (2017). Financial literacy among Mexican high school teenagers. International Review of Economic Educations, 24, 1-17.

7. Ando, A., \& Modigliani. F. (1963). The "Life Cycle" hypothesis of saving: Aggregate implications and tests. The American Economic Review, 53(1), 55-84.

8. Archuleta, K. L., Dale, A., \& Spann, S.M. (2013).College students and financial distress: Exploring debt, financial satisfaction, and financial anxiety. Journal of Financial Counseling and Planning, 24, 2.

9. Bandura, A. (1986). Social foundations or thought and action: A social cognitive theory. Englewood Cliffs, NJ: Prentice -Hall.

10. Chong, M. C., Francis, K., Cooper, S., Abdullah, K.L., Hmwee, N.T. T., \& Sohod, S.(2016). Access to, interest in and attitude toward e-learning for continuous education among Malaysian nurses. Nurse Education Today, 36, 370-374.

11. Chowa, G. A. N., \& Despard, M. R. (2014). The influence of parental socialization on youth financial behavior: Evidence from Ghana. Journal of Family and Economic Issues, 35(3), 376-389.

12. Currás-Pérez, R., Ruiz-Mafé, C., \& Sanz-Blas, S. (2013). Social network loyalty: Evaluating the role of attitude, perceived risk and satisfaction. Social Network Loyalty, 37(1), 61-82.

13. Dohmen, T., Falk, A., Huffman, D., \& Sunde, U. (2012). The intergenerational transmission of risk and trust attitudes. Review of Economic Studies, 79, 645-677.

14. Duh, H.I. (2016).Childhood family experiences and young Generation Y money attitudes and materialism. Personality and Individual Differences, 95, 134-139.

15. Eagly, A. H., \& Chaiken, S. (2007). The advantages of an inclusive definition of attitude. Social Cognition, 25(5), 582-602.

16. Falahati, L., \& Paim, L. (2012). Experiencing financial problems among university students. Gender in Management, 27(5), 315-330.

17. Fan, L., \& Chatterjee, S. (2019). Financial socialization, financial education, and student loan debt. Journal of Family and Economic Issues, 40(1), 74-85. doi:10.1007/s10834-018-9589-0.

18. Fong, K.Y., \& Khoo, C.H. (2015).Attitude, learning environment and current knowledge enhancement of accounting students in Malaysia. Journal of Accounting in Emerging Economic, 5(2), 202-221.

19. Fünfgeld, B., \& Wang, M. (2009). Attitudes and behaviour in everyday finance evidence from Switzerland. International Journal of Bank Marketing, 27(2), 108-128.

20. Gale, G.W., Harris, B. H., \& Levine, R. (2012). Raising household saving: Does financial education work. Social Security Bulletin, 72(2), 39-48.

21. Ibrahim, M. E., \& Alqaydi, F. R. (2013). Financial literacy, personal financial attitude and forms of personal debt among resident of UAE. International Journal of Economic and Finance, 5(7), 126-138.

22. Joo, S., \& Grable, J.E. (2004). An exploratory framework of the determinants of financial Satisfaction. Journal of Family and Economic Issues, 25 (1), 162-171.

23. Kagotho, N., Nabunya, P., Ssewamala, F., Mwangi, E. N. \& Njenga, G. (2017). The role of family financial socialization and management skills on youth saving behavior. Journal of Adolescence. 57,134-138.

24. Klapper, L., Lusardi, A., \& Van Oudheusden, P. (2015). Financial literacy around the world. Standard \& Poor's ratings services Global Financial Literacy Survey, available at: http://media.mhfi.com/ documents/2015-Finlit_paper_17_F3_SINGLES.pdf

25. Lim, T. S., Mail, R., Karim, M. R.A., Ulum, Z. K.A.B., Jaidi, J., \& Noordin, R. (2018). A serial mediation model of financial knowledge on the intention to invest: The central role of risk perception and attitude. Journal of Behavioral and Experimental Finance.20, 74-79.

26. Lin, L., Hsiao, Y., \& Yeh, C. (2017). Financial literacy, financial advisors, and information sources on demand for life insurance. Pacific-Basin Finance Journal, 43, 218-237.

27. Mason, C., \& Madden, R. (2017). Making Prudent Financial Management a Way of Life: The Aspiration of the Credit Counselling and Debt Management Agency (AKPK).Case study. Asian Institute of Finance. 
28. Massis, B. (2015). Hiring for attitude and training for skill in the library. New Library World, 116, 467-470.

29. Maswati, A.T., Abdullah, A., \& Wai, Y.C.(2015). Credit card Practices; Knowledge, attitude and debt management. Pertanika Jurnal Social Sciences and Humanities, 23, 119-142.

30. Mindra, R., \& Moya, M. (2017).Financial self-efficacy: a mediator in advancing financial inclusion, Equality, Diversity and Inclusion. An International Journal, 36(2), 128-149.

31. Mouna, A., \& Anis, J. (2017). Financial literacy in Tunsia. Its determinants and it implication on investment behavior. Research in International Business and Finance, 39, 568-577.

32. Munyoki, I., \& Okech, T. C. (2012). Empirical analysis of personal debt among the Youth in Kenya: The case of graduate in Kenyan University. International Journal of Academic Research in Economic and Management Sciences,1(4), 8-20.

33. Norvilitis, J. M., \& Mendes-Da-Silva, W. (2013). Attitudes towards credit and finance among college students in Brazil and the United States. Journal of Business Theory and Practice, 1(1),132-151.

34. Nyhus, E. K., \& Webley, P. (2013). The relationship between parenting and the economic behaviour and orientation of Norwegian Adolescents. Journal of Genetic Psychology, 176, 620-641.

35. Otto, A., \& Webley, P. (2016). Saving, selling, earning, and negotiating: How adolescents acquire monetary lump sums and who considers saving. Journal of Consumer Affairs, 50 (2), 342-371.

36. Paluri, R.A., \& Mehra, S.(2016). Financial attitude based segmentation of women in India. An exploratory study. Journal of Bank Marketing, 34 (5), 670-689.

37. Parotta, J. L., \& Johnson, P.J. (1998). The impact of financial attitudes and knowledge on financial management and satisfaction of recently married individual. Financial Counseling and Planning, 9, 59-75.

38. Pham, T.H., Yap, K., \& Dowling, N.A. (2012). The impact of financia management practices and financial attitudes on the relationship between materialism and compulsive buying. Journal of Economic Psychology, 33, 461-470

39. Rodrigues, L. P., Oliveira, A., Rodrigues, H., \& Costa, C. J. (2019). Assessing consumer literacy on financial complex products. Journal of Behavioral and Experimental Finance, 22, 93-104.

40. Saurabh, K. \& Nandan, T. (2018). Role of financial risk attitude and financial behavior. As mediators in financial satisfaction: Empirical evidence from India. South Asian Journal of Business Studies, 7(2), 207-224.

41. Simkiv, M. (2013). Money attitudes of Ukraine young people. Socio-demographic aspect. Journal of Education Culture \& Society, 36(10), 36-45.

42. Tsui-Yii, S \& Shen-Chen K. (2014). Determinates of financial behavior: Insight into consumer money attitudes and financial literacy. Services Business, 8(2) 217-238.

43. Shim, S., Barber, B., Card, N., Xiao, J.J., \& Serido, J. (2010). Financial socialization of Young adults: The role of family, work, and education. Journal of Youth and Adolescence, 39, 1457-1470.

44. Skagerlund, K., Lind, T., Strömbäck, C., Tinghög, G., \& Västfjäll, D. (2018). Financial literacy and the role of numeracy-How individuals' attitude and affinity with numbers influence financial literacy. Journal of Behavioral and Experimental Economics, 74, 18-25.

45. Smith, A.A., Synowka, D.P. \& Smith, A.D. (2014). E-commerce quality and adoptive elements of e-ticketing for entertainment and sporting events. International Journal Business Information Systems, 15(4), 450-487.

46. Sohn, S. H., Joo, S.H., Grable, J.E., Lee, S., \& Kim, M.(2012) Adolescents' financial literacy: The role of financial socialization agents, financial experience and money attitudes in shaping financial literacy among South Korean youth. Journal of Adolescence, 35, 969-980.

47. Stumm, S.V., O’Creevy, M.F., \& Furnham, A.(2013). Financial capability, money attitudes and socioeconomic status: Risks for experiencing adverse financial events. Personality and Individual Differences, 54, 344-349.

48. Szymborska, H. K. (2019). Wealth structures and income distribution of US households before and after the Great Recession. Structural Change and Economic Dynamics, 51, 168- 185

49. Wang, L.V, \& Jiang, L. (2011). The impact of attitude variables on the credit debt Behaviour. Nankai Business Review International, 2(2), 120-139.

50. Zhao, X., Deng, S., \& Zhou, Y. (2017). The impact of reference effects on online purchase intention of agricultural products. Internet Research, 27(2), 233-255.

\section{AUTHORS PROFILE}

Mohd Zamri Abu Bakar is a Phd student at Faculty Business Management, University Technology MARA, Malaysia.

Saridan Abu Bakar is working at Arsyad Ayub Graduate Business School, University Technology MARA, Malaysia. 